\title{
MALARI: STUDI GERAKAN MAHASISWA MASA ORDE BARU
}

\author{
Ipong Jazimah*
}

\begin{abstract}
Abstrak
Penelitian ini bertujuan untuk mengungkap: 1) latar belakang terjadinya Peristiwa Malaria 1974; 2) Kronologi peristiwa Malaria 1974; dan 3) Dampak yang ditimbulkan dari peristiwa Malaria 1974 menyangkut kebijakan pemerintah terhadap kegiatan mahasiswa di kampus.

Penelitian ini merupakan penelitian sejarah yang tahapannya meliputi heuristik, kritik sumber (verifikasi), interpretasi dan penyajian (historiografi). Sumber yang akan dipakai dapat dibedakan menjadi dua yaitu sumber primer dan sekunder. Sumber primer yang digunakan adalah koran sejaman, sementara sumber sekunder adalah buku-buku yang ditulis oleh sejarawan berikutnya.

Peristiwa Malari bisa dikatakan sebagai titik awal perlawanan terhadap Soeharto secara besar-besaran, ditandai dengan adanya aksi pembakaran, perusakan, dan kerusuhan yang menyebabkan beberapa korban meninggal dan luka-luka. Sebelum Malari memang telah ada aksi mahasiswa menggugat, aksi Golongan Putih dan sebagainya. Tetapi tidak mampu mengikutsertakan massa dalam jumlah yang cukup signifikan. Namun peristiwa Malari bagi generasi muda yang lahir pada tahun 1973 tidak cukup dikenal dengan baik. Bagi mereka, peristiwa Malari adalah "Peristiwa ribut-ribut di Monas".

Ada juga yang melihat peristiwa Malari sebagai konspirasi para jenderal yang tidak memiliki sandaran politik dalam struktur kala itu, dengan memakai mahasiswa untuk dijadikan alat politik terhadap para petinggi Orde Baru saat itu. Apa pun yang dikatakan oleh generasi muda, namun bagi para pelaku Malari, peristiwa Malapetaka 15 Januari itu adalah momentum awal memanfaatkan kontradiksi di kalangan militer untuk mempertajam kekuatan-kekuataan pro status quo dengan kekuatan yang pro perubahan bagi kepentingan rakyat banyak.
\end{abstract}

Kata kunci: Malari, Gerakan Mahasiswa, Orde baru

\begin{abstract}
Latar Belakang
Lembaran sejarah Indonesia

menunjukkan bahwa kekerasan sering menjadi jalan keluar bagi setiap permasalahan yang muncul. Konflik kekerasan yang terjadi di Indonesia dipicu oleh berbagai alas an, diantaranya masalah perbedaan suku, ekonomi dan politik. Kekerasan juga kerap terjadi pada rakyat oleh pemerintah yang didukung oleh
\end{abstract}

kuatnya kekuasaan militer. Hal itu terjadi karena pemerintah anti terhadap kebebasan berpendapat.

Demokrasi yang mati bertahan cukup lama pada masa era pemerintahan Suharto. Merujuk pada pendapat Edward Shils bahwa pada awal-awal pembangunan Indonesia, kedudukan presiden dan militer adalah saling ketergantungan. Presiden membutuhkan militer untuk 
mempertahankan kekuasaan, sementara militer membutuhkan presiden untuk eksistensi mereka di pemerintahan. Sikap militer pada umumnya anti diskusi, anti kritik, dan anti kebebasan pers (Kartodirjo,1983: 178).

Besarnya kekuasaan yang diberikan presiden kepada militer menjadi alasan kenapa kemudian kekerasan selalu menjadi jalan keluar untuk mengatasi masalah demonstrasi di Indonesia pada masa itu. Peristiwa Malari yang merupakan kependekan dari Malapetaka 15 Januari 1974 adalah titik tolak ketidakpuasaan rakyat terhadap kebijakan pemerintah yang diwakili oleh mahasiswa. Gerakan yang dilakukan oleh mahasiswa tersebut dihadapi dengan kerasnya militer beserta tank-tank bajanya.

Pergerakan mahasiswa, menurut Dhaniel Dhakidae terdiri atas dua kelompok yaitu kelompok yang bergerak atas aspek perjuangan moral yang bergerak atas ukuran benar dan salah, dan kelompok kedua yang bergerak atas perhitungan politik praktis tentang yang kuat dan lemah (Dhakidae, 1983:.47). Bila merujuk pendapat Dhaniel Dhakidae, gerakan mahasiswa yang terjadi pada tahun 1974 pada peristiwa Malari tergolong gerakan mahasiswa pada kelompok pertama yaitu kelompok yang bergerak atas perjuangan moral.

Pasca peristiwa 30 September 1965 gerakan mahasiwa cenderung memakai konsep yang pertama yaitu gerakan moral (moral force) (Suharsih \& Mahendra, tt:77). Mahasiswa muncul sebagai aktor politik ketika bangsa sedang krisis, dan setelah krisis selesai, mereka kemudian kembali ke kampus untuk belajar. Arief Budiman menyebutnya sebagai "Gerakan Koreksi" yaitu gerakan yang tidak harus mengumpulkan massa yang besar dan melengkapi dirinya dengan ideologi alternatif.

Konsep gerakan moral awalnya berasal dari konsep gerakan seorang tokoh cowboy bernama Shane. Sang cowboy datang ke suatu kota kecil yang penuh dengan bandit kejam, lalu dia berhasil menghabisi bandit-bandit itu. Namun saat dia diminta oleh penduduk kota untuk menjadi sherif, dia menolak bahkan pergi dari kota itu. Ilustrasi cerita Shane itulah yang kemudian menjadi gambaran dari konsep gerakan mahasiswa yang terjun dalam mengatasi krisis bangsa tanpa adanya pamrih terhadap materi apalagi kekuasaan.

Gagasan konsep gerakan cowboy Shane tersebut berkembang seiring dengan keinginan mahasiswa untuk 
independen dan menghindari permainan politik. Mereka bukan suatu kelompok politik yang berusaha mendapatkan kekuasaan, melainkan suatu kekuatan moral yang menginginkan negara mencapai cita-citanya. Hal yang senada diungkapkan oleh Soe Hok Gie untuk menggambarkan gerakan mahasiswa dalam meruntuhkan kekuasaan Sukarno.

Perjuangan seorang cowboy berawal ketika dia datang ke sebuah kota dari tempat yang sangat jauh. Di kota itu sedang merajalela perampokan, perkosaan dan ketidakadilan. Cowboy ini menantang sang bandit berduel dan ia menang. Bandit mati dan penduduk kota yang ingin berterima kasih mencari sang cowboy. Tetapi ia telah pergi ke tempat yang sangat jauh. la tidak menginginkan pangkatpangkat atau sanjungan-sanjungan dan cowboy itu akan datang lagi kalau ada bandit-bandit yang menyerang kota.

llustrasi cerita cowboy di atas digunakan oleh Soe Hok Gie untuk menggambarkan gerakan mahasiswa tahun 1966, seperti cuplikan tulisannya berikut ini:

"Ketika mereka (mahasiswa) turun ke "kota" karena terdapat "banditbandit PKI Soekarno-Subandrio" yang sedang menteror penduduk, merampok kekayaan rakyat dan

\begin{abstract}
mencemarkan wanita-wanita terhormat. Mahasiswa ini menantangnya berduel dan menang. Setelah ia menang ia balik lagi ke bangku-bangku kuliah, sebagai mahasiswa yang baik. la tidak ingin mengeksploitir jasajasanya untuk dapat rejeki-rejeki" (Soe Hok Gie, 1983:48).
\end{abstract}

Tahun 1970-an menjadi awal bagi kebangkitan gerakan mahasiswa dari periode sebelumnya yaitu tahun 1968 atau 1969 yang cenderung tenang-tenang saja karena dirasa telah berhasil meruntuhkan kekuasaan Sukarno. Mulai tahun 1970 terjadi berbagai aksi dan protes yang dilakukan oleh mahasiswa. Beberapa alasan yang memicu terjadinya protes adalah masalah pendidikan seperti bertambahnya jumlah mahasiswa tetapi anggaran terhadap pendidikan relatif kurang. Kedua, meningkatnya inflasi dan bertambahnya kesulitan hidup sehari-hari. Ketiga, merajalelanya korupsi sehingga pembangunan hanya dinikmati oleh sekelompok kecil masyarakat.

Mahasiswa mulai melancarkan aksi-aksi yang bersifat spontan, setempat, dan hanya diikuti beberapa bekas tokoh mahasiswa dan pelajar yang sebelumnya turut berperan dalam peristiwa 1966. Selain 
itu protes-protes mahasiswa juga lebih bersifat mengingatkan "mitra lama" tentang penyimpangan yang terjadi seperti isu pemborosan, korupsi, demokrasi, dan sandiwara politik (Naipospos, 1996:25).

Karangan yang ditulis Soe Hok Gie setidaknya dapat menggambarkan bahwa masa tahun 1970-an mahasiswa yang awalnya terlibat aktif dalam gerakan setelah mendapat kekuasaan mulai goyah hati. Mereka tidak lagi seidealis ketika menjadi mahasiswa. Soe Hok Gie mengirimkan alat make up kepada temantemannya sesame mahasiswa pergerakan yang duduk di kursi kekuasaan sebagai simbol bahwa mereka sudah tidak lagi murni untuk berjuang namun lebih disibukkan dengan mencari muka kepada atasan. Isi karangannya juga menggambarkan hal tersebut. Tulis Soe Hok gie "hanya ada dua pilihan, menjadi idealis atau apatis" (Soe Hok Gie dalam Rudy Badil, dkk, 2009:462).

Reaksi pemerintah terhadap gerakan mahasiswa pada sekitar awal tahun 1970-an bersifat toleran. Kritik mahasiswa diperhatikan meskipun prakteknya tidak banyak menunjukkan perubahan. Pada awal tahun 1973 suhu politik semakin memanas, reaksi pemerintah juga berubah. Pemerintah mulai bertindak tegas pada protes pembangunan Taman Mini Indonesia Indah (TMII). Pemimpin aksi protes ditangkap tanpa melalui proses hukum, dan sejumlah surat kabar yang dianggap ikut membakar situasi ditutup dalam beberapa hari. Namun hal tersebut tidak menyurutkan perlawanan yang dilakukan oleh mahasiswa.

Akhir tahun 1973 intensitas gerakan mahasiswa semakin meningkat, apalagi Dewan Mahasiswa mempunyai kekuatan tambahan dari organisasi ekternal kampus. Peristiwa besar meledak saat Perdana Menteri Jepang Kakuei Tanaka datang ke Indonesia. Peristiwa itulah yang kemudian dikenal dengan Malapetaka 15 Januari atau Malaria. Peristiwa Malari sangat menarik untuk diteliti. Selain bentuk gerakan yang dilakukan oleh mahasiswa, akibat yang ditimbulkan pun juga luar biasa besar bagii perkembangan perpolitikan di Indonesia. Peristiwa Malari juga merupakan potret bagaimana demokrasi berusaha dibungkam dengan senjata dan militer.

Tahun-tahun itu pemerintah mulai bertindak tidak bersahabat. Pemerintah menuduh mahasiswa ditunggangi oleh kepentingan politik tertentu. Istilah ditunggangi kemudian menjadi istilah resmi pemerintah bagi gerakan mahasiswa selanjutnya. Dengan istilah ditunggangi pemerintah menunjukkan kesan seolaholah bersimpati kepada mahasiswa, namun 
bila ada aksi yang tidak berkenan di mata pemerintah langsung dicap dengan kata "ditunggangi" (Naipospos, 1996:.26).

Peristiwa ini berawal dari kedatangan Perdana Menteri (PM) Jepang Kakuei Tanaka yang berkunjung ke Jakarta pada tanggal 14-17 Januari 1974. Mahasiswa merencanakan menyambut kedatangannya dengan berdemonstrasi di pangkalan Udara Halim Perdanakusuma, namun karena dijaga ketat rombongan mahasiswa kemudian menerobos masuk pangkalan udara. Suasana kota Jakarta sudah mencekam ditandai dengan keberangkatan Perdana Menteri Kakuei Tanaka dari istana yang tidak menggunakan mobil, melainkan diantar Presiden Soeharto dengan helikopter.

Peristiwa Malari dapat dilihat dari berbagai perspektif. Sejarawan Asvi Warman Adam (2003) melihat ada dua kategori untuk Malaria yaitu demonstrasi mahasiswa menentang modal asing, terutama Jepang dan bentuk ketidaksenangan kaum intelektual terhadap Asisten pribadi presiden Soeharto yaitu Moertopo, Soedjono Humardani, dan lainlain yang memiliki kekuasaan teramat besar.

Berpijak pada pendapat Frances Stewart (dalam Dewi Fortuna Anwar, 2005) peristiwa Malari dapat dikategorikan sebagai kontrak sosial yang gagal. Protes terjadiii ketika negara gagal memainkan perannya dalam kontrak sosial yaitu sebagai penyedia pelayanan ekonomi dan sosial. Pada kontrak social, rakyat menerima wewenang Negara sepanjang Negara memberikan layanan dan menciptakan kondisi ekonomi yang memadai dari segi pekerjaan dan penghasilan. Apabila terjadi stagnasi ekonomi, kemunduran, dan layanan pemerintah memburuk, kontrak social tidak lagi berlaku, akibatnya terjadi protes dan kekerasan.

Rakyat melalui mahasiswa menilai bahwa kebijakan Negara untuk bekerjasama dengan Jepang dalam bidang ekonomi yang ditandai dengan kedatangan Perdana Menteri Kakuei Tanaka tidak akan menyelesaikan masalah ekonomi yang sedang dihadapi justru menambah beban Negara yaitu hutang.

Peristiwa ini penting untuk diangkat menjadi sebuah penelitian sejarah karena peristiwa 15 Januari 1974 dapat disebut sebagai salah satu tonggak sejarah kekerasan Orde Baru dan sejak itu kebijakan dijalankan secara lebih sistematis. Dalam buku Otobiografinya yang terbit tahun 1989, Soeharto tidak menyinggung kasus Malari 1974. Padahal mengenai "petrus" 
(penembakan misterius), Soeharto cukup berterus terang. Ini membuktikan bahwa ada yang disembuyikan dari peristiwa Malaria 1974.

Peristiwa Malari yang meletus tahun 1974 dimungkinkan memang sengaja dibuat untuk menjatuhkan Jenderal Sumitro karena Presiden Suharto tidak suka ada orang lain yang popularitasnya melebihi dirinya. Jenderal Sumitro sebelumnya memang banyak membuat gebrakan yang menyebabkan namanya menjadi populer. Diantaranya adalah kebijaksanaannya agar fraksi $A B R I$ dalam MPR tidak mendukung konsep Undang-Undang Perkawinan buatan Golkar yang ditolak oleh kelompok Islam, dan agar fraksi ABRI menolak usaha yang hendak menjadikan aliran kebatinan sebagai agama yang resmi diakui di Indonesia layaknya Islam, Kristen, Hindu, dan Budha.

Kajian-kajian yang menulis tentang Malari sudah cukup banyak, karena itu untuk mencegah terjadinya perluasan pembahasan maka penelitian ini dibatasi hanya pada tahun 1974 sesaat sebelum peristiwa dan sesaat setelah peristiwa. Akibat yang ditimbulkan juga dibatasi hanya pada masalah politik terutama akibatnya pada perkembangan gerakan mahasiswa, sementara akibat di bidang ekonomi dan hubungan dengan luar negeri tidak dikaji.

Berdasarkan latar belakang yang disampaikan di atas serta pembatasan masalahnya, maka rumusan masalahnya adalah sebagai berikut:

1. Apa latar belakang terjadinya Peristiwa Malaria 1974?

2. Bagaimana kronologi peristiwa Malaria 1974 ?

3. Apa dampak yang ditimbulkan dari peristiwa Malaria 1974 menyangkut kebijakan pemerintah terhadap kegiatan mahasiswa di kampus?

\section{Tinjauan Pustaka}

Penelitian ini mengkaji sumbersumber tertulis yang terdiri dari buku, surat kabar, jurnal penelitian, majalah, dan internet. Sumber buku yang digunakan diantaranya adalah karangan $\mathrm{B}$. Wiwoho dan Bandjar Chaeruddin, Memori Jendral Yoga, (Tanpa kota: PT. Bina Rena Pariwara, Tanpa tahun). Pada Bab 11 di buku itu membahas tentang tentang pengakuan Jenderal Yoga yang merupakan salah satu orang yang terlibat langsung dalam peristiwa tersebut.

Sumber selanjutnya adalah buku karangan dari Suharsih dan Ign. Mahendra K, Bergerak Bersama Rakyat: Sejarah 
Gerakan Mahasiswa dan Perubahan Sosial di Indonesia, (Yogyakarta: Resist Book, Tanpa Tahun). Buku ini menceritakan secara lebih detail gerakan mahasiswa dilmulai dari tahun setelah tumbangnya Sukarno.

Sumber lain adalah Bonar Tigor Naipospos, Mahasiswa Indonesia dalam Panggung Politik ke arah Gerakan Rakyat? dalam majalah prisma tertanggal 7 Juli 1996. Kedua sumber di atas sama-sama menyatakan bahwa gerakan mahasiswa 1974 merupakan bentuk perlawanan mahasiswa terhadap sikap pemerintah yang tidak pernah berpihak pada rakyat kecil. Keduanya juga menyinggung konsep gerakan mahasiswa sebagai gerakan moral.

\section{Metode Penelitian}

Menurut Helius Syamsudin (2007) tahapan dalam penelitian sejarah meliputi heuristik, kritik sumber (verifikasi), interpretasi dan penyajian (historiografi). Heuristik adalah pengumpulan sumber. Pada tahap ini, peneliti melakukan penelusuran sumber ke Perpustakaan Pascasarjana UNS, Perpustakaan Pusat UNS, Perpustakaan IKIP PGRI Madiun, Perpustakaan Kollese Ignatius, Perpustakaan Daerah Yogyakarta,
Perpustakaan Malioboro Yogyakarta dan Pusat Informasi Kompas di Yogyakarta. Sumber yang akan dipakai dapat dibedakan menjadi dua yaitu sumber primer dan sekunder. Sumber primer yang digunakan adalah koran sejaman, sementara sumber sekunder adalah bukubuku yang ditulis oleh sejarawan berikutnya.

Verifikasi adalah meneliti sumber untuk menentukan validitas dan reliabilitas sumber sejarah. Terdiri dari Kritik intern dan Kritik ekstern. Pada tahap kritik intern, peneliti menyelidiki isi berita, sumber berita, narasumber yang dimintai, hingga kredibilitas surat kabar tentang peristiwa Malari 1974. Pada tahap Kritik ekstern, peneliti mencari jawaban terhadap keaslian dan keutuhan sumber yang dipakai.

Interpretasi adalah tahapan dimana peneliti menghubungkan fakta-fakta sejarah yang diperoleh setelah proses verifikasi, karena fakta-fakta sejarah tersedia dalam bentuk terpisah-pisah dan besar kemungkinan dipengaruhi oleh para pemikiran sejarawan. Tahap yang terakhir adalah historiografi atau penyajian. Pada tahap ini peneliti menyajikan semua data yang telah terseleksi dan telah diinterpretasikan berdasarkan prinsip kronologi. 
Hasil Penelitian dan Pembahasan

1. Latar Belakang Peristiwa Malari 1974

a. Panasnya Suhu Politik Tahun 1970-an

Sejak tahun 1970 terjadi berbagai aksi dan protes yang dilakukan oleh mahasiswa. Ada beberapa alasan yang menyebabkan terjadinya aksi tersebut yaitu jumlah mahasiswa yang terus bertambah namun anggaran pendidikan kurang, jumlah mahasiswa baru tidak sepadan dengan fasilitas yang tersedia, inflasi meningkat sehingga menambah kehidupan semakin susah. Ditambah dengan merajalelanya korupsi yang mengiringi pertumbuhan ekonomi, dan pembangunan yang tidak menyejahterakan rakyat karena hanya dinikmati oleh segelintir kelompok tertentu.

Sejalan dengan kenaikan harga bensin dan semakin meningkatnya praktek korupsi, para aktivis mahasiswa yang diantaranya adalah Victor D, Arief Budiman, Syahrir, dan Julius Usman membentuk gerakan mahasiswa bernama "Mahasiswa Menggugat". Bagi mereka lebih baik

mengutamakan

pemberantasan korupsi daripada menaikkan harga bensin. Sementara mahasiswa Bandung yang tergabung dalam kelompok Studi Grup Mahasiswa Indonesia pada 21 Januari 1970 mengeluarkan sebuah petisi yang berjudul "Petisi Keadilan" (Suharsih \& Mahendra, tt:79). Mereka menuntut agar pemerintah melakukan kontrol yang ketat terhadap penggunaan dan pembagian uang negara. Apabila tuntutan tersebut tidak dipenuhi maka rakyat tidak akan menerima keputusan tentang kenaikan harga bensin.

Memasuki bulan Juli di tahun 1970, protes terhadap praktek korupsi semakin gencar karena imbas dari korupsi adalah fasilitas kampus yang semakin menyusut. Kondisi belajar yang kurang nyaman dirasakan oleh mahasiswa di Fakultas Kedokteran Universitas Indonesia, Universitas Padjajaran, dan mahasiswa di Yogyakarta. Mahasiswa membentuk Komite Anti Korupsi (KAK) yang dipimpin oleh Arief Budiman, Syahrir, dan Marsilam 
Simanjuntak.

Sementara

mahasiswa Bandung yang tergabung dalam kelompok Studi Grup Mahasiswa Indonesia membentuk "Bandung Bergerak" yang sejalan dengan arah perjuangan KAK. Walaupun pada awalnya mereka mencurigai gerakan Arief Budiman dkk telah ditunggangi oleh partai politik tertentu. Pada saat itu aksi saling curiga menjadi hal yang biasa karena derasnya provokasi terhadap mahasiswa dari berbagai pihak Kedua kelompok mahasiswa dari Jakarta dan Bandung tersebut mendatangi berbagai pejabat tinggi di kementerian, menempelkan poster-poster anti korupsi di kantor Pertamina dan Kejaksaan Agung.

$$
\text { Aksi protes dari }
$$
mahasiswa semakin panas dan berani, maka muncullah ide untuk mengadakan malam tirakatan pada malam 15 Agustus 1970 yang bertempat di Jalan Thamrin Jakarta. Namun rencana tersebut ditentang oleh Panglima Komando Pemulihan Keamanan dan Ketertiban (Pangkopkamtib) yaitu Jenderal Soemitro. Bahkan ia mengancam jika mahasiswa tetap melaksanakan kegiatan tersebut akan dikirim tentara untuk membubarkan. Dari sini sudah dimulai ancaman oleh militer dalam menyelesaikan konflik.

$$
\text { Perbedaan pendapat }
$$
antara pihak mahasiswa dan pihak tentara tersebut dicairkan oleh Gubernur Jakarta Ali Sadikin dengan mengajukan pemecahan agar kegiatan tirakatan tetap dilaksanakan namun di rumah masing-masing. Gubernur Jakarta Ali Sadikin berjanji akan memadamkan lampu di wilayah kekuasaannya selama 5 menit. Kesepakatan tersebut akhirnya diterima oleh mahasiswa dan tentara. Ada satu tokoh yang tidak bersedia mematuhi kesepakatan antara mahasiswa dan tentara yang diusulkan oleh Ali Sadikin, yaitu penyair muda WS. Rendra. Dia tetap datang ke Jalan Thamrin untuk mengadakan kegiatan tirakatan disana. Akibatnya dia ditangkap oleh tentara. Parlemen kemudian bersedia membahas tentang Rancangan UndangUndang Anti Korupsi sehingga mahasiswa untuk sementara berhenti bergerak. 
Ketenangan mahasiswa

kembali terusik menjelang pemilu tahun 1971 saat banyak aktivis mahasiswa yang menyuarakan massa agar mendukung bahkan mencoblos Golkar. Salah satu tokoh mahasiswa yaitu Arief Budiman tidak setuju dengan aksi aktivis mahasiswa tersebut kemudian melakukan gerakan yang dinamakan "Golongan Putih". Gerakan yang dibentuk oleh Arief Budiman bertujuan untuk menghimpun orang-orang yang tidak ikut pemilu dan mengkritik mahasiswa yang mendukung Golkar.

Gerakan "Golongan Putih" tidak mampu membendung suara yang didapatkan oleh Golkar karena Golkar keluar sebagai pemenang pemilu 1971. Setelahnya Suharto menekan partai politik dengan menggabungkan sembilan partai politik menjadi dua partai besar yaitu Partai Persatuan Pembangunan (PPP) untuk partai Islam dan Partai Demokrasi Indonesia (PDI) untuk partai nasionalis dan Kristen (Suharsih \& Mahendra, tt:79). Bahkan kebijakan yang lebih menekan dikeluarkan sehubungan dengan pelarangan pendirian kantor partai di pedesaan selain Golkar.

\section{b. Protes TMII}

Protes mahasiswa kembali muncul ketika lbu Tien Suharto mengusulkan pembangunan Taman Mini Indonesia Indah (TMII) pada tahun 1973. Pembangunan TMII menurut kelompok mahasiswa dianggap tidak sesuai dengan situasi negara yang sedang kesulitan keuangan. Reaksi bermunculan dengan keluarnya berbagai gerakan yang mengatasnamakan penghematan uang Negara.

Gerakan-gerakan itu diantaranya Gerakan Penghemat, Gerakan Akal Sehat (GAS), dan Gerakan Penyelamat Uang Rakyat. Pemerintah kemudian bersikap represif dengan melarang semua gerakan anti TMII. Tokoh-tokoh pemimpin gerakan mahasiswa ditangkap, diantaranya Arief Budiman dan H.J Princen. Beberapa koran juga ditutup dan wartawan mengalami berbagai tekanan. Persoalan itu kemudian dibawa ke meja DPR, dan 
ditindaklanjuti

dengan

pembentukan Komisi Penyelidik

yang akhirnya menghasilkan

sebuah keputusan bahwa

pembangunan TMII dilanjutkan

dengan syarat tidak boleh

menikmati fasilitas keuangan dari

negara dan juga tidak ada

sumbangan wajib.

Di tahun yang sama

tepatnya bulan Oktober para

mahasiswa mengadakan aksi ke

gedung MPR/DPR untuk

menyampaikan petisi bernama

"Petisi 24 Oktober". Petisi tersebut berisi krtitikan terhadap kebijakan pembangunan yang dianggap tidak populis dan hanya menguntungkan kelompok yang kaya. Gerakan itu tidak meluas karena hanya berpusat di Jakarta. Pada saat itu konsep gerakan moral masih dipakai oleh mahasiswa, yaitu mahasiswa hanya sebatas mengkritik kebijakan pemerintah.

Isi dari petisi tersebut adalah:

1) Strategi pembangunan perlu ditinjau kembali. Strategi yang baru hendaknya menciptakan keseimbangan di bidang politik, sosial, dan ekonomi.
2) Rakyat harus dibebaskan dari ketidakpastian hukum, korupsi, serta penyelewenganpenyelewengan kekuasaan.

3) Perlunya refungsionalisasi lembaga-lembaga penyalur pendapat rakyat.

4) Penentuan masa depan adalah hak dan kewajiban generasi muda (Wiwoho \& Chaeruddin, $\mathrm{tt}: 228)$.

Sementara itu mahasiswa dari Jawa Timur seperti Universitas Brawijaya, IKIP Malang, Universitas Negeri Jember, IAIN, Institut Teknologi Surabaya, dan Universitas Airlangga mengeluarkan "Maklumat 73" yang berisi sebagai berikut:

a) Bahwa suksesnya pelaksanaan pembangunan membutuhkan pemerintahan yang berwibawa dan bersih serta berorientasi pada kepentingan rakyat

b) Motivasi pembangunan yang fundamental memerlukan pembinaan pendidikan yang demokratis dan dilaksanakan secara sungguh-sungguh serta ditunjang oleh anggaran yang cukup. 


\section{c. Isu Modal Asing}

Di kalangan pengusaha terjadi rivalitas antara kelompok yang terpusat pada dua tokoh yaitu Jenderal Soemitro dan Jenderal Ali Murtopo. Jenderal Soemitro adalah Panglima Komando Pemulihan Keamanan dan Ketertiban (Pangkopkamtib), sementara Jenderal Ali Murtopo adalah Asisten Pribadi (Aspri) Presiden dan Kepala Operasi Khusus (Opsus). Mahasiswa mulai melancarkan aksi kritik terhadap pembangunan yang berlandaskan bantuan asing yang akhirnya melahirkan pemerasan negara dan ketidakadilan sosial, karena adanya beberapa orang Jepang dan Cina yang bekerjasama dengan tokoh nasional untuk "menjual" Indonesia.

Pada tanggal 6 November 1973 bertempat di Computer Centre UI telah berlangsung sebuah diskusi yang bertema "Penilaian Situasi Terakhir". Diskusi tersebut dikoordinasikan oleh Hariman Siregar dan Syahrir dengan mendatangkan beberapa penceramah antara lain Ashadi Siregar, Fauzi, dan Chalid Aini yang ketiga-tiganya dari Grup Diskusi Juli Yogyakarta. Diskusi ini membahas tentang pelaksanaan pembangunan yang dirasakan pincang.
Keesokan harinya yaitu tanggal 7 November 1973, Hariman Siregar dan Gumilang Kartasasmita mensponsori kuliah taman di Fakultas Ekonomi UI dengan penceramah Dorodjatun Kuntjorojakti. Mereka menyoroti masalah penanaman modal asing di Indonesia, terutama modal Jepang. Sedangkan dalam diskusi keesokan harinya di Lembaga Manajemen UI menghadirkan tema “Evaluasi Politik Luar Negeri”. Diskusi tersebut juga diprakarsai oleh Hariman Siregar yang merupakan ketua DM-UI dan Hermawan ketua SM Fakultas Kedokteran dengan menghadirkan penceramah dari luar yaitu Dr. Sudjatmoko.

Selain menyelenggarakan diskusi-diskusi, para mahasiswa juga melakukan pertemuan-pertemuan yang cukup intensif. Pada tanggal 10 November 1973 pengurus Dewan Mahasiswa (DM) dari berbagai perguruan tinggi (UI, ITB, ITT, IKIP Bandung, Unpar, Unpad, Unbraw, dan ITS) mengadakan pertemuan tertutup di Bandung. Mereka mencapai kesepakatan bersama untuk mengadakan langkah-langkah bersama dengan gerakan serentak. 
Pada tanggal 11 November 1973 di kampus ITB dilakukan pertemuan tertutup oleh Dewan Mahasiswa yang mengambil keputusan untuk terus membangkitkan aksi spontanitas. Pengurus DM-UI dalam hal ini Hariman Siregar, mengatakan bahwa hukum positif yang berlaku sekarang ini menghambat proses modernisasi kultural, karena tidak sesuai dengan kebutuhan dan tuntutan zaman. Mahasiswa sangat menyesalkan banyaknya sarjana hukum yang hanya berpegang pada nilai normatif, yang terlihat dari banyaknya vonis hukuman bagi koruptor sama dengan pencuri ayam, juga penyesalan akan banyaknya pejabat yang pandai bicara tapi tidak mampu bertindak tegas.

Sebenarnya diantara kalangan mahasiswa sendiri juga terdapat perbedaan persepsi. Ada yang beranggapan bahwa pelaku gerakan dari mahasiswa bisa dibeli sehingga perjuangan yang sebenarnya kandas. Hariman Siregar sebagai ketua DM-UI sangat aktif mengkoordinasikan gerakan-gerakan mahasiswa.setelah dari Bandung, ia berangkat ke Yogyakarta untuk mengadakan pertemuan dengan para pemimpin mahasiswa. Pada saat yang bersamaan Senat Mahasiswa FE-UI mengeluarkan pernyataan sebagai berikut:

1) Mendesak pemerintah untuk membersihkan para pejabat yang menyalahgunakan

wewenang/kedudukan dan mengambil keuntungan pribadi dalam pelaksanaan penanaman modal asing.

2) Tenaga asing harus memahami/mengenal kebudayaan dan adat istiadat bangsa Indonesia, bukan sebaliknya para karyawan Indonesia harus tunduk pada adat istiadat mereka.

3) Pemerintah perlu segera menyusun program yang realistis dan lengkap guna memberikan perlindungan kepada pengusahapengusaha kecil.

4) Modal asing harus menunjang tercapainya tujuan pembangunan dan dapat memberikan kesempatan kerja lebih banyak kepada rakyat ((Wiwoho \& Chaeruddin, tt:228).

Di Balai Budaya Jakarta diselenggarakan diskusi bertema "Untung Rugi Modal Asing di Indonesia" dengan moderatornya 
adalah Mochtar Lubis. Sedangkan para pembahasnya adalah Dorodjatun Kuntjorojakti, Maruli Panggabean dan Suhadi. Diskusi di luar kampus itu diikuti oleh sejumlah mahasiswa dan seorang peserta dari Fakultas Sastra UI yaitu Sylvia Gunawan yang membacakan "Ikrar Warganegara Indonesia" yang isinya adalah sebagai berikut:

Kami warganegara Indonesia yang berkumpul pada tanggal 30 November malam bertempat di Balai Budaya, menyadari akan arah perkembangan pembangunan ekonomi dan sosial bangsa pada dewasa ini, berikrar:

- Menegakkan kembali kebanggaan nasional yang sebagian telah dicemarkan oleh berbagai kalangan masyarakat

- Menggunakan dengan segala cara yang berdasarkan konstitusi untuk menegakkan kembali kebanggaan nasional tersebut

- Menetapkan hari ini, tanggal 30 November 1973 sebagai titik tolak usaha ini (Wiwoho \& Chaeruddin, tt:228).
Setelah ikrar tersebut dibacakan, kemudian diedarkan untuk mendapatkan tandatangan dari orangorang yang menyetujuinya, dan ternyata berhasil mengumpulkan 155 penandatangan antara lain Mochtar Lubis, Yap Thiam Hien, Adnan Buyung Nasution, Taufik Abdullah, Yuwono Sudarsono, Dorodjatun Kuntjorojakti, Marsilam Simandjuntak, Remy Leimena, Hariman Siregar, Yozar Anwar, Louis Wangge, dan lainlainnya.

Puncak aksi terhadap isu modal asing adalah saat datangnya Menteri Kerjasama Belanda yaitu Pronk ke Jakarta. Pronk yang merupakan ketua IGGI disambut dengan demonstrasi oleh mahasiswa Indonesia. Bahkan saat berkunjung ke Yogyakarta Pronk juga disambut demonstrasi oleh GMII (Gerakan Mahasiswa Indonesia untuk rakyat Indonesia). Mahasiswa menyerukan anti modal asing, dan kedatangan Pronk dianggap sebagai lambang ketergantungan Indonesia terhadap modal asing.

Selain melakukan aksi, beberapa kelompok mahasiswa juga mendatangi pimpinan Badan Koordinasi Penanaman Modal (BKPM) 
untuk mengajukan beberapa pertanyaan seputar modal asing. Bahkan delegasi mahasiswa dari ITB mendatangi Bappenas dan menuntut agar permainan kotor modal asing tidak diteruskan. Selain itu Dewan Mahasiswa dari ITB, Unpad, dan Unpar berdemonstrasi di depan kedutaan Jepang untuk mengutuk kerjasama modal Jepang.

\section{Peristiwa Malari 1974}

\section{a. Kedatangan Perdana Menteri \\ Tanaka}

Pada tanggal 9 Januari 1974, sebelum kedatangan Perdana Menteri Tanaka, para mahasiswa telah berdemonstrasi menentang para Asisten Pribadi (Aspri) presiden. Di Jakarta dan Bandung terjadi pembakaran boneka-boneka yang menggambarkan Soedjono Humardani dan Perdana Menteri Jepang, Tanaka.

Para Aspri menyerang balik mahasiswa, mereka menuduh mahasiswa telah ditunggangi oleh kekuatan luar yang anti Suharto.

Tanggal 11 Januari, Presiden Suharto menerima delegasi DewanDewan Mahasiswa yang menyampaikan kecaman dan mempertanyakan kewibawaan presiden yang dirongrong tingkah laku para pemimpin yang memperkaya diri secara tidak sah. Opsus yang dipimpin Ali Moertopo memiliki kekuasaan yang besar melebihi pemerintah dan parlemen.

Pertemuan antara delegasi mahasiswa dan Presiden Suharto tidak menghasilkan apa-apa karena presiden tidak mengambil keputusan apapun. Dari situlah kemudian mahasiswa melalui sebuah Apel Siaga Mahasiswa di kampus UKI pada tanggal 12 Januari mengajak masyarakat untuk menyambut Perdana Menteri Tanaka dengan gerakan aksi. Mahasiswa juga mengajak masyarakat untuk memasang bendera setengah tiang pada hari kehadiran Perdana Menteri Tanaka, selain itu juga mengajak koran untuk memboikot pemberitaan tentangnya, dan mengadakan aksi total pada tanggal 15 Januari 1974.

Pada tanggal 14 Januari 1974 mahasiswa berdemonstrasi di lapangan udara Halim Perdanakusuma sebagai protes atas kedatangan Perdana Menteri Tanaka. Namun pada hari itu belum terjadi bentrokan, situasi masih berjalan dinamis. Mahasiswa menonjolkan isu-isu tentang keresahan masyarakat, anti cukong dan modal 
asing terutama dari Jepang. Nantinya gerakan-gerakan tersebut mengarah pada tindakan kerusuhan karena sudah melibatkan berbagai elemen, tidak hanya mahasiswa saja.

Tanggal 15 Januari 1974 para mahasiswa berkumpul di Fakultas Kedokteran UI Jalan Salemba. Mereka menyusun kembali Tritura yang berisi 1) Bubarkan Aspri 2) Turunkan harga 3) Ganyang korupsi ((Suharsih \& Mahendra, tt:82). Tuntutan untuk membubarkan Aspri oleh mahasiswa dari awal ditanggapi Ali Moertopo, bahwa hal tersebut adalah hak sepenuhnya presiden. Nantinya Aspri akan dipertahankan atau dibubarkan, keputusannya berada di tangan presiden.

Setelah itu mahasiswa bergerak ke Monumen Nasional (Monas) di Lapangan Merdeka. Dalam perjalanan, jumlah massa semakin bertambah karena para pelajar juga ikut masuk dalam barisan mahasiswa. Massa aksi yang terdiri dari pelajar dan mahasiswa ini kemudian bergerak menurunkan bendera-bendera penyambutan tamu negara yang ada di sepanjang pinggir jalan menjadi setengah tiang sebagai tanda duka cita atas kedatangan Perdana Menteri Tanaka.

Perdana Menteri Jepang Tanaka dan putrinya Makiko beserta rombongan menyentuh landasan Halim Perdanakusuma pukul 19.45 pada tanggal 14 Januari 1974. Kedatangan tamu Jepang itu tidak disambut dengan upacara militer kenegaraan, setelah itu segera rombongan Perdana Menteri Jepang Tanaka disertai Presiden Suharto menuju Wisma Negara dengan menaiki mobil Mercedes-600 "Indonesia I". Sementara demonstrans yang gagal masuk ke Halim Perdanakusuma berusaha menyelundupkan beberapa orang menerobos pengamanan. Pada hari itu aksi demonstrans tidak terlalu beringas, karena itu mereka merencanakan keesokan harinya dengan aksi yang lebih tajam.

\section{b. Tanggal 15 Januari sebagai}

\section{Puncak Aksi}

Sejak pagi pada tanggal 15 Januari 1974 arus massa datang dari berbagai jurusan ke lapangan Monas. Pasukan keamanan semakin memperkuat diri dengan kendaraan lapis baja yang berjaga-jaga disekitar pintu Istana Merdeka. Pagi itu merupakan jadwal dimana Perdana 
Menteri Jepang Tanaka akan mengadakan perundingan dengan Presiden Soeharto. Sementara itu mahasiswa terus mempersiapkan diri, dengan sebelumnya berkumpul di kampus UI pada pukul 09.00. Mereka lebih dulu mendapatkan pengarahan dari sejumlah tokoh mahasiswa teruatama Bambang Sulistomo. Setelah itu mahasiswa bergerak menuju kampus Usakti melalui kampus UKI.

Mahasiswa dari Usakti itu dijemput dengan beberapa kendaraan yang membawa mereka ke Monas untuk bergabung dengan teman-teman mahasiswa yang lain. Lalu lintas pada hari itu sangat macet, apalagi mahasiswa yang bergerak ke Istana Merdeka semakin mendesak untuk dapat memberikan memorandum kepada Perdana Menteri Jepang Tanaka, walaupun akhirnya gagal.

Aksi berlanjut dengan pencegatan mobil-mobil Jepang di jalanan yang menyuruh pengemudinya keluar. Banyak toko-toko yang rusak akibat massa yang beringas, dan barisan mahasiswa sudah bercampur dengan barisan dari luar sehingga susah dikendalikan. PT. Toyota Astra merupakan perusahaan patungan
Indonesia-Jepang yang menderita kerugian paling besar. Kantornya dirusak dan mobil yang berada di ruang pamer dibakar massa.

Demonstrasi tanggal 15 Januari masih berlanjut sampai tanggal 16 Januari dengan massa masih memenuhi jalan-jalan utama di Jakarta. Hari itu bus-bus kota masih belum beroperasi, sehingga para karyawan dan pegawai berangkat ke kantor mereka dengan berjalan kaki. Suasana hari itu masih panas dan diliputi duka karena telah jatuh korban beberapa orang meninggal dan luka-luka. Pengurus Dewan Mahasiswa seJakarta pada hari itu kemudian mengeluarkan pernyataan yang isinya:

1) Tindakan perusakan yang terjadi di Jakarta, termasuk pembakaran dan kegiatan destruktif lainnya yang menjurus ke tindakan anarki, adalah perbuatan yang tidak bertanggungjawab dan nyata-nyata bertentangan serta merusak citra mahasiswa.

2) Menyesalkan dan menyatakan prihatin terhadap kejadian yang telah mengakibatkan kerugian material dan moral di kalangan masyarakat tersebut. 
3) Menyerukan kepada seluruh mahasiswa untuk tetap siaga di tempat, tidak terpancing provokasi dan tetap memelihara ketertiban.

4) Menyerukan agar masyarakat membantu menjaga ketertiban demi tercapainya aspirasi perjuangan mahasiswa yang murni (Wiwoho \& Chaeruddin, tt:240241).

Pada saat demonstran mendekati istana presiden, massa semakin tidak terkontrol dan meletuslah kerusuhan besar. Massa membakar mobil-mobil Jepang serta mengobrak-abrik pertokoan. Saat massa mulai beranjak untuk bergerak ke arah kedutaan Jepang, Jenderal Sumitro datang untuk menenangkan massa sambil memberi janji-janji akan memenuhi seluruh tuntutan mahasiswa, terutama tuntutan untuk membubarkan Aspri. Mahasiswa kemudian membatalkan tujuannya kearah kedutaan Jepang dan kembali ke Salemba. Namun massa yang tidak terkontrol tetap membuat kerusuhan sepanjang malam, sehingga malam tanggal 15 Agustus 1974 adalah malam yang mencekam.

Keesokan harinya tanggal 16 Januari 1974 pagi, Jenderal Soemitro didampingi para Aspri melancarkan ultimatum dan mengancam akan menggunakan kekerasan apabila massa tetap tidak dapat dikendalikan. Pemerintah kemudian menggunakan Hariman Siregar untuk menenangkan massa, ia ditampilkan di TV membacakan deklarasi dari Dewan Mahasiswa Universitas Indonesia yang menentang tindakan-tindakan kekerasan.

\section{d. Reaksi Masyarakat Pasca}

\section{Peristiwa Malari}

Pasca peristiwa Malari yang terjadi pada tanggal 15 Januari 1974 , pernyataan dari berbagai pihak bermunculan untuk menanggapi kejadian tersebut. Berbagai organisasi massa juga mengeluarkan pernyataan yang pada umumnya mencela tindakan perusakan dan pembakaran tersebut. Sejumlah organisasi mengharapkan pemerintah menyelesaikan masalah itu dengan sebaik-baiknya tanpa melakukan kekerasan. Golkar, PPP, dan PDI mengeluarkan aksi mereka pada hari pertama berlangsungnya aksi perusakan dan pembakaran, ketigatiganya mencela kejadian huru-hara pada tanggal 15 Januari 1974.

Pada tanggal 19 Januari 1974 Pengurus Pusat PWI (Persatuan 
Wartawan Indonesia) menyerukan jajaran pers ibukota dan daerah untuk menghindari pemberitaan yang dapat mengganggu pembangunan, mendukung usaha pemerintah untuk menertibkan kembali keadaan dan agar pelaksanaannya sesuai dengan azas hukum. Sementara dari kalangan mahasiswa muncul reaksi yang berbeda-beda, dari mahasiswa IKIP Bandung mengeluarkan pernyataan yaitu:

1) Tetap meneruskan perjuangan suci mahasiswa dengan pola dasar perjuangan mengikis habis kepincangan-kepincangan sosial dengan segala konsekuensinya.

2) Tetap mengkonsolidasikan diri dalam kelompok mahasiswa, berjuang dengan pimpinan IKIP Bandung serta siap sedia setiap saat.

3) Menyatakan bela sungkawa/duka cita sedalam-dalamnya atas korban-korban yang jatuh pada aksi perjuangan mahasiswa dalam menegakkan keadilan sosial (Wiwoho \& Chaeruddin, tt:24).

Sembilan dosen UGM Yogyakarta menyatakan situasi pergolakan mahasiswa itu tidak dapat dipandang sebagai hal yang berdiri sendiri, tetapi menyangkut realita sosial yang diakibatkan oleh kebijakan pemerintah dalam menanggapi masalah kehidupan masyarakat. Mereka berharap pemerintah bertindak bijaksana dan lebih menghargai kehidupan rakyat, serta tidak mudah menggolongkan luapan-luapan perasaan masyarakat sebagai usaha makar.

Reaksi kalangan pers nasional bermacam-macam. Harian Indonesia Raya menulis "Diharapkan agar oknum-oknum yang tidak bertanggungjawab segera dapat diseret ke pengadilan, bila pemerintah tidak menanggapi secara positif apa yang disuarakan oleh para mahasiswa, maka peristiwa serupa akan terjadi lagi di kemudian hari". Harian KAMI menyatakan "Gerakan mahasiswa/pemuda itu hendaknya tidak dinilai sebagai taraf kekerasan, apalagi makar, bila motivasi kepemimpinan nasional betul-betul akan diletakkan atas dasar dedikasi, kejujuran serta keterbukaan".

Harian Pedoman menulis hal yang berbeda "Tindakan penghancuran atas barang-barang modal akan bisa menghilangkan kepercayaan luar negeri terhadap Indonesia". Harian 
Kompas menulis "Usaha mahasiswa Igenerasi muda untuk menyalurkan aspirasi rakyat demi kepentingan mereka telah berkembang di luar kontrol dan tujuannya. Tidak tertutup kemungkinan ada pihak lain seperti gerakan PKI ikut mengambil bagian".

\section{Dampak Peristiwa Malari 1974}

\section{a. Pemerintah Mengambil Tindakan}

\section{Tegas}

Kerusuhan yang terjadi tanggal 15 Januari 1974 membuat pusat kota Jakarta sempat terhenti aktivitasnya selama dua hari. Hampir 50 mobil yang kebanyakan buatan Jepang dan 144 gedung dibakar atau dirusak. Sementara korban dari manusia adalah 9 orang meninggal, 100 lebih cedera, 820 lebih ditangkap.

Pada beberapa sumber jumlah korban dan barang rusak memang tidak sama persis namun sama-sama menunjukkan besarnya kerugian yang dialami masyarakat akibat kerusuhan yang terjadi bersamaan dengan peristiwa Malari. Ada hal yang menarik berkaitan dengan perusakan mobil dan motor, karena yang dirusak hanyalah mobil dan motor buatan Jepang, sementara mobil dan motor buatan negara lain tidak dirusak. Ini menunjukkan antipasti masyarakat dan demonstran terhadap segala sesuatu yang berasal dari Jepang.

Setelah peristiwa Malari 1974 pemerintah memberlakukan jam malam untuk wilayah Jakarta dari pukul 18.0006.00 pagi. Ketentuan tersebut terus berlaku sampai ada ketentuan baru lagi yang dikeluarkan oleh pemerintah. Setelah itu banyak sekolah dan universitas yang tutup, mereka tidak berani untuk beraktivitas seperti biasa karena takut dihadang massa yang lebih radikal dari sebelumnya.

Universitas Indonesia yang dianggap sebagai basis massa mahasiswa dijaga ketat oleh $A B R I$. Pemberlakuan jam malam itu kemudian resmi dicabut pada tanggal 21 Januari 1974, 7 hari setelah meledaknya peristiwa Malari. Hal tersebut diungkapkan oleh Laksus Pangkopkamtib Daerah Jakarta Raya dan sekitarnya, Mayjend J.H Mantik. Pencabutan jam malam tersebut berhubungan dengan kondisi kota Jakarta dan sekitarnya yang sudah berjalan normal kembali.

Secara bertahap beberapa Koran ditutup. Tahap pertama pada tanggal 15 Januari 1974 adalah Nusantara dan Mahasiwa Indonesia. Tahap kedua tanggal 21 Januari 1974 
yaitu Harian KAMI, Indonesia Raya, Abadi, dan The Jakarta Times. Tahap ketiga tanggal 23 Januari 1974 yang ditutup adalah Pedoman dan Ekspres. Pemerintah menganggap koran-koran terus-menerus melakukan provokasi yang mengganggu ketertiban umum, sehingga perlu ditertibkan.

Akibat peristiwa tersebut, ratusan orang ditangkap yang dianggap sebagai provokasi kerusuhan. Dewan Mahasiswa dianggap sebagai penggerak mahasiswa dalam peristiwa Malari itu sehingga para ketuanya yang akan dimintai pertanggungjawaban (Kedaulatan Rakyat, 19 Januari 1974). Empat puluh lima orang ditahan diantaranya yaitu Rahman Tolleng, Hariman Siregar, Subadio Sastrosatomo, Prof. Sarbini Sumawinata (mantan pemimpin PSI), Dorodjatun Kuntjoro-Jakti, dan H.J. Princen (Ketua Liga Hak-Hak Azazi Manusia) serta aktivis-aktivis muda Islam yang lain. Ke-45 orang yang ditangkap dianggap sebagai otak dari demonstrasi Malari yang menyebabkan terjadinya kerusuhan hebat. Bahkan Ali Moertopo dan Aspri menuduh adanya usaha makar yang dilakukan mahasiswa yang didalangi oleh PSI dan Masyumi secara tidak langsung.

Presiden Suharto setelahnya memberikan pernyataan bahwa segala macam bentuk demokrasi harus ditegakkan dan dibina terus-menerus. Namun demokrasi yang diiringi dengan kekerasan hanya akan menimbulkan dampak negatif yang tidak baik bagi perkembangan bangsa dan negara terutama para pemuda penerus bangsa. Pernyataan presiden tersebut disampaikan saat pengambilan sumpah ketua dan wakil ketua Mahkamah Agung yaitu Oemar Soeaji dan Santoso Pujosubroto. Demokrasi yang tidak hati-hati menurut presiden hanya akan menimbulkan kerusuhan dan kerusakan, lebih lanjut presiden meinta agar kasus peristiwa Malari segera dituntaskan.

b. Pemerintah

Mengatur

\section{Kegiatan Dewan Mahasiswa}

Setelah peristiwa Malari 1974 kontrol terhadap Dewan Mahasiswa (DM) dan Majelis Permusyawaratan Mahasiswa (MPM) sangat ketat dilakukan. Berkenaan dengan kegiatan mahasiswa di kampus, pemerintah mengeluarkan Surat Keputusan Pemerintah No. 028/1974. SK itu memberikan wewenang yang besar 
kepada pimpinan perguruan tinggi untuk mengontrol mahasiswa (Kedaulatan Rakyat, 24 Januari 1974)

Langkah lain yang dilakukan pemerintah adalah keputusan bahwa mahasiswa harus mendapatkan ijin untuk semua aktivitasnya di kampus, pers mahasiswa harus diawasi oleh Menteri Penerangan dan birokrat kampus, peraturan bahwa organisasi mahasiswa yang berafiliasi dengan partai politik untuk bergabung menjadi satu organisasi yang diatur oleh rejim, serta penggunaan pancasila sebagai alat kontrol politik.

Mahasiswa semakin terdesak dengan berbagai peraturan yang dikeluarkan oleh pemerintah kemudian. Bahkan yang ekstrim, demonstrasi dilarang, dan bagi siapa saja yang menjadi pemimpin demonstrasi akan ditangkap. Apabila mahasiswa demonstrasi maka akan berhadapan dengan ABRI. Sebagian pihak menyesalkan keputusan pemerintah itu karena hal tersebut dapat menyumbat jalannya demokrasi yang harusnya berjalan seirama dengan pertumbuhan nasional. Segala tindakan yang berbau politis di kampus harus melalui rektor, sejalan dengan kebijakan yang baru dikeluarkan oleh pemerintah untuk alasan stabilisasi negara.

Tidak hanya kampus yang terkena imbas dari peristiwa Malari, sesuai dengan tuntutan demonstrasi presiden kemudian menghapuskan jabatan Aspri dan jabatan Pangkopkamtib langsung berada di tangan presiden. Keputusan tersebut diambil tanggal 28 Januari 1974 siang di Istana Merdeka setelah terjadi pertemuan antara presiden Suharto dan wakil presiden Hamengkubuwono IX. Pertemuan tersebut juga melibatkan para petinggi negara yang lain dan juga petinggi militer. Keputusan tersebut sudah dipertimbangkan matangmatang dengan melihat situasi dan kondisi negara. Bahkan untuk menindaklanjuti agar keamanan negara terus terjaga, pemerintah kemudian membentuk Dewan Stabilisasi Politik dan Keamanan Nasional yang diketuai langsung oleh Presiden Suharto dengan wakil ketuanya adalah wakil presiden Hamengkubuwono IX.

\section{c. Opini Yang Terbentuk Di Luar Negeri}

Banyak opini dari luar negeri yang bermunculan setelah peristiwa Malari 1974 meletus. Perdana Menteri Jepang Tanaka dalam konperensinya persnya di Tokyo pada tanggal 18 
Januari 1974, menyatakan bahwa para pejabat Indonesia memang risau menghadapi demonstrasi di Jakarta. Tetapi ia sendiri tidak terlalu khawatir meski hal-hal semacam itu, besar atau kecil, masih bisa terjadi lagi. la menyatakan telah berusaha membuka telinga lebar-lebar untuk mendengarkan aspirasi dan keluhan mahasiswa Indonesia, dan berjanji akan memperbaikinya bila memang terdapat kesalahan-kesalahan.

$$
\text { Menlu Jepang Masayoshi }
$$

Ohiro juga menyatakan, Jepang perlu memperbaiki apa yang harus diperbaikinya untuk dapat memperdalam rasa saling pengertian antara kedua bangsa. Jepang berharap rakyat Indonesia menilai baik terhadap niat baik dan bantuan Jepang untuk memperbaiki situasi ekonomi serta kesejahteraan rakyat Indonesia.

Ketua Dewan Perdagangan Luar Negeri Jepang, Tatsuzo Hizamuki menyatakan, rakyat dan pemerintah Jepang hendaknya mempelajari kembali sikap-sikap mereka terhadap negara-negara lain, terutama negaranegara berkembang. la juga mengatakan bahwa banyak patokan yang sudah tidak dipatuhi oleh pengusaha Jepang di luar negeri.
Sejumlah pengusaha Jepang menyatakan akan memeriksa kembali seluruh kebijaksanaan mereka di Asia dan meneliti kemajuan ekonomi Jepang di kawasan itu, mengingat sentimen anti Jepang tercermin jelas, terutama dalam kerusuhan di Jakarta.

Reaksi pers luar negeri pun menunjukkan perhatian mendalam terhadap kerusuhan Jakarta, hampir semua surat kabar Jepang menyoroti peristiwa tersebut. Diantara surat kabar tersebut adalah Asahi Shimbun menyatakan bahwa perasaan anti Jepang memang terus memuncak, kunjungan Tanaka hanya merupakan sumbu peledak dari bom waktu perasaan anti Jepang itu. Sebelumnya sudah diduga bahwa kunjungan Tanaka itu merupakan kunjungan kekerasan, tapi kekerasan dalam perundingan dan bukan kerusuhan. Demonstrasi-demonstrasi di Malaysia dan Thailand serta kerusuhan di Jakarta merupakan insiden yang mengejutkan.

Surat kabar Jepang yang lainnya yaitu Yumiori Shimbun, Mainichi Shimbun, dan Japan Times juga menurunkan editorial mereka. Sedangkan surat kabar Korea Selatan umumnya menyatakan sudah 
waktunya Jepang mengoreksi kesalahan-kesalahannya dalam berhubungan dengan negara tetangga yang miskin. Sementara surat kabar Australia, Sydney Morning Herald menyatakan bahwa Tanaka sekembalinya ke Jepang hendaknya menemukan keyakinan bahwa politik komersial dan metode perdagangan Jepang di luar negeri memerlukan perubahan radikal.

Surat kabar Singapura, The Strait Times menyatakan bahwa pemerintah Indonesia yang mulanya bersikap mengalah kepada para mahasiswa, telah salah menilai besarnya perasaan anti Jepang atau tidak ingin memperkecil perasaan tidak puas mahasiswa dengan situasi ekonomi dalam negeri. Surat kabar Singapura yang lain, New Nation menyatakan penanaman modal Jepang yang meningkat di Indonesia membangkitkan ketakutan terhadap kolonisasi ekonomi Jepang. Tidak mengherankan bila para mahasiswa yang militan kemudian memanfaatkan kunjungan Tanaka untuk menunjukkan rasa tidak senang mereka.

Reaksi juga muncul dari sejumlah organisasi mahasiswa di luar negeri. UMSU (University Of Malay
Student Union) di Kuala Lumpur mengirim kawat kepada pemerintah RI untuk meminta perhatian terhadap para pemimpin mahasiswa Indonesia. Selain itu Persatuan Mahasiswa Australia juga mengajukan protes lewat nota mereka kepada Kedubes RI di Canberra. Mereka bahkan mengancam akan melakukan demonstrasi ke Kedubes Jepang.

Reaksi yang disampaikan oleh surat kabar asing berkaitan dengan peristiwa Malari teryata sama sekali tidak mempengaruhi bursa valuta asing (Kedaulatan Rakyat, 30 Januari 1974). Hal tersebut berarti bahwa tidak ada peningkatan atau penurunan mata uang rupiah terhadap mata uang asing lainnya. Hal tersebut disampaikan oleh Gubernur Bank Indonesia Rachmad Saleh dalam sidang dewan stabilisasi yang dipimpin oleh presiden Suharto di Bina Graha tanggal 29 Januari 1974.

\section{Simpulan}

Peristiwa Malari bisa dikatakan sebagai titik awal perlawanan terhadap Soeharto secara besar-besaran, ditandai dengan adanya aksi pembakaran, perusakan, dan kerusuhan yang menyebabkan beberapa korban meninggal dan luka-luka. Sebelum Malari memang 
telah ada aksi mahasiswa menggugat, aksi Golongan Putih dan sebagainya. Tetapi tidak mampu mengikutsertakan massa dalam jumlah yang cukup signifikan. Namun peristiwa Malari bagi generasi muda yang lahir pada tahun 1973 tidak cukup dikenal dengan baik. Bagi mereka, peristiwa Malari adalah "Peristiwa ribut-ribut di Monas".

Ada juga yang melihat peristiwa Malari sebagai konspirasi para jenderal yang tidak memiliki sandaran politik dalam struktur kala itu, dengan memakai mahasiswa untuk dijadikan alat politik terhadap para petinggi Orde Baru saat itu. Apa pun yang dikatakan oleh generasi muda, namun bagi para pelaku Malari, peristiwa Malapetaka 15 Januari itu adalah momentum awal memanfaatkan kontradiksi di kalangan militer untuk mempertajam kekuatan-kekuataan pro status quo dengan kekuatan yang pro perubahan bagi kepentingan rakyat banyak.

\section{Daftar Pustaka}

\section{Buku}

B. Wiwoho dan Bandjar Chaeruddin. Tanpa tahun. Memori Jenderal Yoga. Tanpa Kota: PT. Bina Rena Pariwara.

Bonar Tigor Naipospos. 1996. Mahasiswa Indonesia dalam Panggung Politik ke arah Gerakan Rakyat? dalam Prisma, 7 Juli 1996

Daniel Dhakidae. 1983. Soe Hok Gie Sang Demonstran. Jakarta: LP3ES.
Dewi Fortuna Anwar (ed). 2005. Konflik Kekerasan Internal: Tinjauan Sejarah Ekonomi-Politik dan Kebijakan di Asia Pasifik. Jakarta: Yayasan Obor Indonesia.

Helius Syamsudin. 2007. Metodologi Sejarah. Yogyakarta: Penerbit Ombak.

Machiavelli, Niccolo. 2002. Sang Penguasa. Jakarta: Gramedia.

Miriam Budiharjo. 2002. Dasar-dasar IImu Politik. Jakarta: Gramedia.

Rudy Badil, dkk, 2009, Soe Hok Gie Sekali Lagi: Buku Pesta dan Cina di Alam Bangsanya. Jakarta: KPG.

Shils, Edward. Angkatan Bersenjata dalam Pembangunan Politik Negara-Negara Baru, dalam Sartono Kartodirjo (ed). 1983. Elite dalam Perspektif Sejarah. Jakarta: LP3ES.

Soe Hok Gie. 1983. Catatan Seorang Demonstran. Jakarta: LP3ES.

Suharsih \& Ign. Mahendra K. Tanpa Tahun. Bergerak Bersama Rakyat: Sebuah Gerakan Mahasiswa dan Perubahan Sosial di Indonesia. Yogyakarta: Resist Book.

\section{Internet}

Asvi Warman Adam. Malari dan Sisi gelap Sejarah. Kompas Online (16 Januari 2003) diakses hari Sabtu 26 Juni 2010 jam 10.30

Jopie Lasut. Peringatan 30 Tahun Malari Generasi Muda Tak Paham Maknanya. http://www.sinarharapan.co.id diakses rabu, 28 April 2009 jam 15.51

\section{Surat Kabar}

\section{Masa Kini}

Senin Legi, 7 Januari 1974. Petisi Aktivitas 66: Pemerintah Jangan Lupakan Tritura.

Jumat Kliwon, 11 Januari 1974. Menteri Emil Salim Akui Memang Ada Cukongisme dan Korupsi. 
Sabtu Legi, 12 Januari 1974. Anggota DPR H. Moh. Djamhari: Pidato Presiden Kurang Lengkap, antara lain Tidak Singgung-Singgung Usaha Pembersihan Aparatur Pemerintahan dan Pemberantasan Korupsi.

Selasa Wage, 15 Januari 1974. PM Tanaka Tiba di Jakarta Disertai 6 Dirjen.

Kamis Pon, 24 Januari 1974. Keterangan Pemerintah tentang Peristiwa 14-16 Januari 1974.

Senin Pahing, 28 Januari 1974. Keterangan Pemerintah tentang Peristiwa 14-16 Januari 1974.

Rabu Kliwon, 16 Januari 1974. Puncak Demonstrasi Mahasiswa di Jakarta: 50 Mobil Buatan Jepang Dibakar, Jam Malam Mulai Berlaku di Jakarta.

Rabu Kliwon, 16 Januari 1974. Presiden Suharto: Kunjungan PM Tanaka Tepat Waktu.

Rabu Kliwon, 16 Januari 1974. Keamanan di Ibukota Mengkhawatirkan, Beberapa Panser Berjaga-Jaga di Beberapa Tempat, Puluhan Demonstran LukaLuka dan Jalan-Jalan Sepi.

Rabu Kliwon, 16 Januari 1974. Bendera Setengah Tiang Ditancapkan di Uii Yogya.

Rabu Kliwon, 16 Januari 1974. Jangan Meletakkan ABRI sebagai Musuh Mahasiswa.

Kamis Legi, 17 Januari 1974. Sangkar Terhunus Menghadang di Malioboro.

Kamis Legi, 17 Januari 1974. PM Tanaka Puas.

Kamis Legi, 17 Januari 1974. PenangkapanPenangkapan Diadakan di Jakarta.

Kamis Legi, 17 Januari 1974. Para Demonstran Alihkan Aksi Mereka: 7 Orang Dikabarkan Tewas.

Sabtu Pon, 19 Januari 1974. Kampus UGM Dikepung Panser dan Moncong Senjata, Mahasiswa Berjamaah Jumat Diujung Bayonet Terhunus.

Sabtu Pon, 19 Januari 1974. Tanaka Mendadak Adakan Pertemuan dengan Menteri Kabinet.
Sabtu Pon, 19 Januari 1974. KBRI Tokyo Didatangi Mahasiswa.

Sabtu Pon, 19 Januari 1974. Jepang mulai Mawas Diri.

Sabtu Pon, 19 Januari 1974. Demo-demo di Jakarta Dipanggil Pangkopkamtib.

Sabtu Pon, 19 Januari 1974. Tanaka Mendadak Adakan Pertemuan Dengan Kabinet Jepang.

Senin Kliwon, 21 Januari 1974. Gerakan Mahasiswa Terbukti Bermaksud Adakan Tindakan Maker

Rabu Pahing, 23 Januari 1974. Presiden Suharto: Demonstran Bukan Kebebasan Lemparkan Kekecewaan.

Rabu Wage, 30 Januari 1974. Peristiwa 15 Januari 1974 Tak Bawa Pengaruh Negative terhadap Bursa Valuta Asing.

\section{Kedaulatan Rakyat}

Rabu Kliwon, 16 Januari 1974. Jakarta JamMalam, Sekolah-Universitas Tutup.

Jumat Pahing, 18 Januari 1974, Demontrasi Akan Ditertibkan Juga Pemberitaan Surat Kabar: Peristiwa Jakarta Memalukan Bangsa.

Sabtu Pon, 19 Januari 1974. Pimpinan Delapan Dema di Jakarta Dimintai Pertanggunganjawab, Berhubung Demonstrasi Destruktif 15 Januari.

Senin Kliwon, 21 Januari 1974, Demonstrasi Tetap Dilarang, yang Melanggar Ditindak Tegas.

Selasa Legi, 22 Januari 1974, Peristiwa 15 Januari Diungkap Menhankam Jendral Panggabean di DPR.

Rabu Pahing, 23 Januari 1974, Penggunaan Kebebasan Tidak Berhati-Hati.

Kamis Pon, 24 Januari 1974, Presiden

Perintahkan Universitas Segera Dinormalisir 